\title{
DESAIN DAN IMPLEMENTASI SISTEM KONTROL PUTARAN ROL PENARIK DAN PENGEPRES PLASTIK PADA MESIN PENGEMAS JAHE BUBUK
}

\author{
Safila Bachtiar Lutfi \\ Fakultas Teknik, Program Studi Teknik Mesin \\ Universitas Muria Kudus \\ Email: safila.bachtiar619@gmail.com \\ Masruki Kabib \\ Fakultas Teknik, Program Studi Teknik Mesin \\ Universitas Muria Kudus \\ Email: masruki.kabib@umk.ac.id \\ Taufiq Hidayat \\ Fakultas Teknik, Program Studi Teknik Mesin \\ Universitas Muria Kudus \\ Email : taufiq.hidayat@umk.ac.id
}

\begin{abstract}
ABSTRAK
Mesin pengemas jahe bubuk membutuhkan sistem pengendali untuk proses penarikan dan pengepresan plastik. Tujuan dari penelitian adalah untuk mendesain dan mengimplementasikan sistem kontrol putaran rol untuk proses penarikan dan pengepresan plastik pada mesin pengemas jahe bubuk. Metodologi yang digunakan dalam desain dan implementasi sistem kontrol pada mesin pengemas jahe ini diawali dengan kajian pustaka, desain sistem kontrol lup terbuka, gambar desain sistem kontrol, diagram blok sistem kontrol, instalasi hardware dan pengujian. Proses perancangannya meliputi perancangan desain sistem kontrol yang akan dikendalikan, pemrograman, dan perakitan sistem kontrol pada mesin. Hasil pada sistem kontrol mesin pengemas jahe yaitu dapat mengendalikan putaran motor stepper untuk proses penarikan dan pengepresan plastik pengemas jahe dengan kecepatan putar motor $135 \mathrm{rpm}$ dan kecepatan rol $58 \mathrm{rpm}$.
\end{abstract}

Kata kunci : mesin pengemas, penarikan plastik, pengepresan plastik, sistem kontrol.

\section{ABSTRACT}

The powder ginger packaging machines are requires a control system for the plastic retract and sealing process. The objective of the research is to design and implement a roller rotation control system for the process of retract and sealing the plastic on the powder ginger packaging machine. The methodology used in the design and implementation of control systems on the ginger packaging machine begins with a literature review, open loop control system design, control system design drawings, control system block diagrams, hardware instalation and testing. The design process includes the design of a control system that will be controlled, programming, and assembling the control system on the machine. The results on the ginger packaging machine control system were to control the rotation of the stepper motor for the process of drawing and pressing the ginger packaging plastic with a rotational speed of $135 \mathrm{rpm}$ and a roller speed of $58 \mathrm{rpm}$.

Keywords: packaging machines, retract plastic, sealing plastic, control systems. 


\section{PENDAHULUAN}

Teknologi saat ini berkembang sangat cepat, hal ini mendorong berkembangnya dunia elektronika yang pada mulanya menggunakan cara konvensional berubah menggunakan cara modern dengan memanfaatkan kemajuan teknologi. Teknologi bukan hanya di sektor industri saja, sektor diluar pun telah memanfaatkan penggunaan kemajuan teknologi [1] .

Teknologi yang semakin berkembang, timbul kecenderungan diterapkannya sistem pengendalian secara otomatis dalam proses industri modern. Peralatan-peralatan dalam kehidupan sehari-hari yang bekerja berdasarkan pada posisi atau sudut yang sesuai kebanyakan masih dilakukan secara manual. Mikrokontroler (software) dengan peralatan mekanik dan elektronik (hardware) merupakan perpaduan dimensi baru yang sedang diminati banyak orang. Sistem pengendalian yang digunakan adalah dengan komunikasi serial berbasis mikrokontroler [2].

Sistem kontrol dalam perkembangannya banyak diterapkan di industri, sebelumnya banyak pekerjaan menggunakan gerakan mekanik, kemudian beralih menggunakan mesin berbasis sistem kontrol. Sistem kontrol memiliki manfaat antara lain dapat menjamin kualitas produk yang dihasilkan, mengurangi waktu produksi dan mengurangi biaya untuk tenaga kerja manusia [3]. Sistem kendali umpan balik sering disebut sebagai sebuah sistem kendali lup tertutup sedangkan kendali lup terbuka merupakan sistem dengan keluaran yang tidak mempengaruhi fungsi kontrol. Sistem kendali lup terbuka, keluaran tidak dibandingkan dengan referensi masukan [4].

Sistem kontrol banyak dijumpai di industri pengemasan, kapasitas produksi yang tinggi menuntut proses produksi yang lebih cepat dan efisien. Manusia yang berperan dalam proses produksipun diminialisir agar produk bisa lebih baik hasilnya. Proses pembuatan produk-produk makanan hingga pengemasan sekarang ini banyak menggunakan sistem otomatis. Proses yang sangat menyita waktu dan tenaga kerja di industri salah satunya yaitu proses pengemasan produk ke dalam plastik [3].

Sistem kontrol yang berfungsi mengatur kecepatan rooling otomatis untuk penarikan dan pengepresan plastik kemasan yang dilakukan oleh mikrokontroler untuk menggerakan sebuah roll dengan mekanisme gerak motor stepper dalam sistem gerak perpindahan plastik [5]

Motor stepper adalah perangkat elektromekanis yang bekerja dengan mengubah pulsa elektronis menjadi gerakan mekanis diskrit. Motor stepper bergerak berdasarkan urutan pulsa yang diberikan kepada motor stepper. Pulsa digital yang diberikan pada stator motor stepper akan menjadi gerak rotasi pada bagian rotornya. Pulsa digital yang diberikan pada belitan stator akan menyebabkan rotor bergerak sepanjang sudut tertentu, sudut tersebut dinamakan step angle. Pulsa digital pada belitan stator itu sendiri menyebabkan rotor bergerak satu langkah yang panjang langkahnya dinyatakan oleh nilai step angle. Motor stepper untuk memenuhi satu putaran penuh, beberapa pulsa harus diberikan pada motor stepper. Motor stepper dengan demikian bergerak langkah demi langkah dengan panjang langkah yang sama [6]. Sistem kendali ini dapat dipraktekan secara manual untuk mengendalikan sistem kontrol untuk mesin pengemas. Sistem yang otomatis dalam alat ini banyak digunakan didalam bidang industri dalam kehidupan seahari-hari sering dipakai untuk mempermudah produksi pengemasan dimana kendali sering dipakai [7].

Sistem kontrol pada mesin pengemas jahe bubuk bertujuan untuk merancang dan membuat sistem kontrol putaran motor stepper untuk proses penarikan dan pengepresan plastik pengemas jahe bubuk.

\section{METODOLOGI PENELITIAN}

Desain dan implementasi sistem kontrol pada mesin pengemas jahe memerlukan beberapa langkahlangkah yang dapat dilihat pada diagram alir penelitian pada gambar 1 berikut ini. 


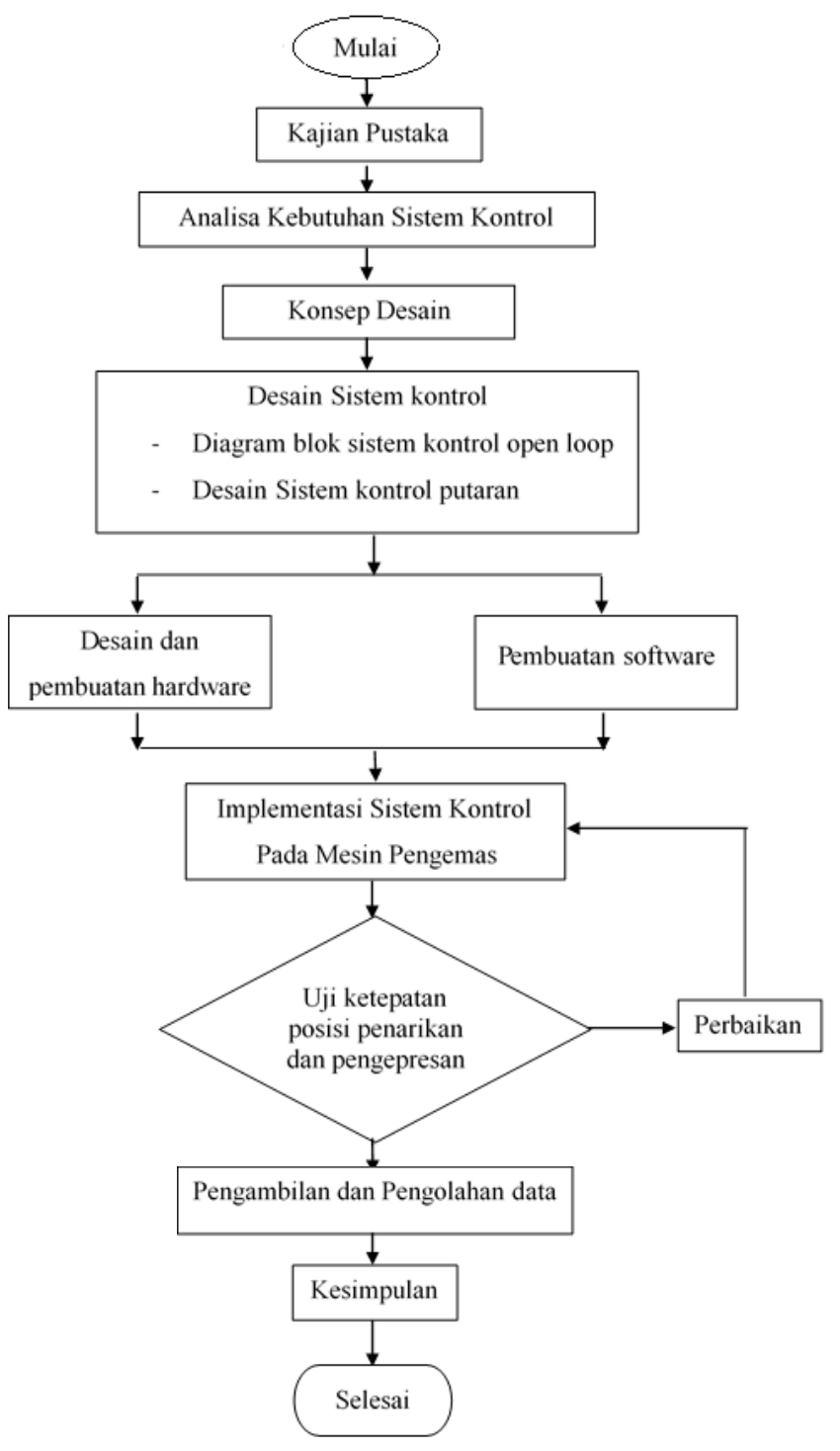

Gambar 1. Diagram alir penelitian

Studi Literatur untuk mencari sumber-sumber terkait dan informasi yang sebelumnya telah dilakukan tentang sistem kontrol pada mesin pengemas jahe dalam suatu penelitian. Konsep desain dilihat dari analisa kebutuhan yang meliputi aspek desain, aspek teknik, aspek manufaktur dan aspek keselamatan kerja. Desain dan perhitungan sistem kontrol mesin pengemas jahe meliputi perhitungan penarikan plastik, penarikan pengepresan plastik, perhitungan motor stepper, desain hardware dan perancangan software sistem kontol. Pengujian ketepatan penarikan dan pengepresan plastik, selanjutnya pengambilan dan pengolahan data.

\section{HASIL DAN PEMBAHASAN}

\subsection{Analisa Kebutuhan Sistem Kontrol}

Dalam proses desain dan perancangan sistem kontrol analisa kebutuhan sistem kontrol mesin harus memenuhi beberapa aspek yaitu :

1. Aspek desain 
Aspek desain sistem kontrol meliputi perhitungan ketepatan penarikan dan pengepresan, desain system control lup terbuka, proses pembuatan sistem kontrol dan komponen yang digunakan relatif mudah didapat dan murah, dan perawatan sistem kontrol yang relatif mudah dan murah.

2. Aspek manufaktur

Kontruksi perancangan sistem kontrol pembuatan box sistem kontrol agar komponen kelistrikan harus tertata rapi. Perancangan mekanisme pengaturan putaran motor. Kebutuhan komponen sistem kontrol meliputi arduino, kabel, power supply, driver, dan motor stepper.

3. Aspek Teknik

Aspek teknik yaitu tentang cara kerja komponen yaitu, Motor stepper 1 berputar menggerakkan dua roll yang berhimpitan dan roll itu akan menarik plastik dari tempat plastik menuju ke roll pengepresan, Setelah plastik sampai ke roll pengepresan, plastik akan di press menggunakan roll yang dikasih heater yang di gerakkan oleh motor stepper 2, Sistem dirancang untuk pengendalian putaran motor stepper untuk ketepatan posisi penarikan dan pengepresan plastik.

4. Aspek Keselamatan Kerja

Keselamatan kerja berperan sangat penting dalam melakukan pekerjaan dan juga dengan pemilihan jenis material sistim kontrol yang digunakan bersifat aman tidak membahayakan, Perancangan catu daya pada sistem kontrol diletakan pada box yang telah disesuaikan dengan desain mesin, sehingga keselamatan terjamin, Sistem kontrol menggunakan arus DC, dan Input sumber listrik AC diubah menjadi DC

\subsection{Proses Perancangan Sistem Kontrol}

\subsubsection{Analisa Penarikan Plastik}

Roll plastik yang ditarik menggunakan 2 rol yang saling berhimpitan yang digerakkan menggunakan motor stepper mekanisamenya dapat digambarkan seperti gambar gambar 2. dibawah ini :

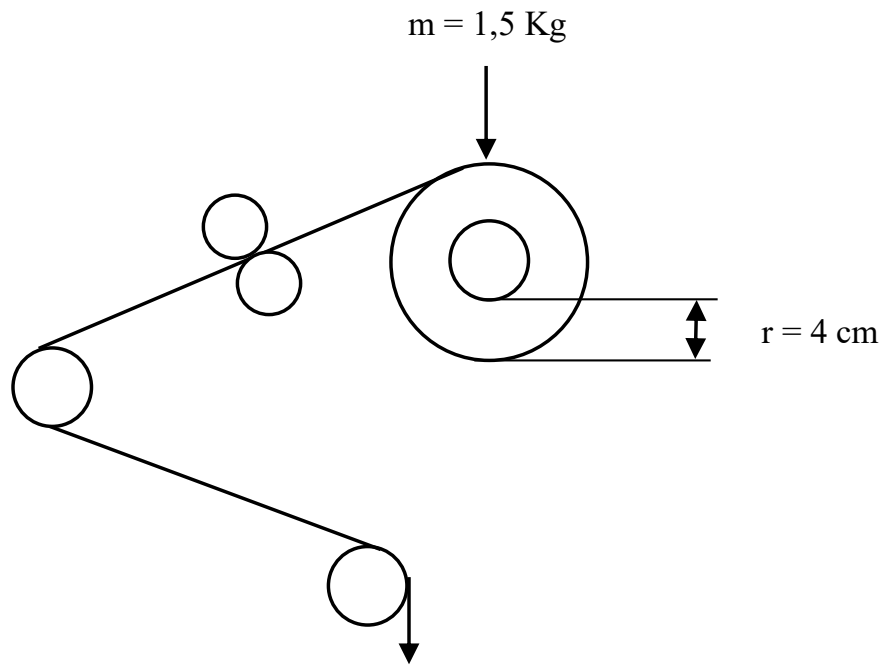

Gambar 2. Mekanisme Penarikan Plastik

1. Gaya yang dibutuhkan untuk menarik plastik dapat menggunakan persamaan 1 sebagai berikut.

$$
F=m \cdot g \cdot \mu
$$

Dimana m adalah massa plastik+rol $(\mathrm{kg})$, g adalah percepatan gravitasi $\left(\mathrm{m} / \mathrm{s}^{2}\right)$, dan $\mu$ adalah koefisien gesek. 
2. Torsi untuk penarikan plastik dapat dihitung menggunakan persamaan 2 berikut [3].

$\mathrm{T}=\mathrm{F} \cdot \mathrm{r}$

Dimana $\mathrm{T}$ adalah torsi $(\mathrm{N} \cdot \mathrm{m}), \mathrm{F}$ adalah gaya $(\mathrm{N})$, dan $\mathrm{r}$ adalah Jari-jari roll plastik (m).

3. Momen inersia untuk menggerakkan plastik dapat menggunakan persamaan 3 berikut

$$
\mathrm{I}=\mathrm{m} \cdot \mathrm{r}^{2}
$$

Dimana I adalah momen inersia $\left(\mathrm{kg} . \mathrm{m}^{2}\right)$, $\mathrm{m}$ adalah beban plastik $(\mathrm{kg})$, dan $\mathrm{r}$ adalah jari-jari roll plastik (m).

Hasil perhitungan gaya penarikan plastic ditunjukkan pada tabel 1 .

Tabel 1. Perhitungan penarikan plastik

\begin{tabular}{ccc}
\hline $\mathrm{F}(\mathrm{N})$ & $\mathrm{T}(\mathrm{N} \cdot \mathrm{m})$ & $\mathrm{I}(\mathrm{kg} \cdot \mathrm{m} 2)$ \\
\hline 0,25 & 0,0125 & 0,0024 \\
\hline
\end{tabular}

\subsubsection{Analisa roll pengepresan plastik}

1. Gaya yang dibutuhkan untuk pengepresan horizontal dapat menggunakan persamaan 4 berikut [8].

$$
\mathrm{F}=\mathrm{P} \cdot \mathrm{A}
$$

Dimana $\mathrm{F}$ adalah gaya pengepresan $(\mathrm{N}), \mathrm{P}$ adalah tekanan $\left(\mathrm{N} / \mathrm{mm}^{2}\right)$ dan $\mathrm{A}$ adalah luas penampang $\left(\mathrm{mm}^{2}\right)$.

2. Torsi untuk pengepresan horizontal dapat dihitung menggunakan persamaan 5 berikut [3].

$$
T=F \cdot D
$$

Dimana $\mathrm{T}$ adalah torsi $(\mathrm{N} \cdot \mathrm{m}), \mathrm{F}$ adalah gaya pengepresan $(\mathrm{N})$, D adalah diameter roll press $(\mathrm{m})$. Gasil perhitungan rol pengepresan plastic di tunjukkan pada tabel 2 .

Tabel. 2 Perhitungan rol pengepresan plastik

\begin{tabular}{cc}
\hline $\mathrm{F}(\mathrm{N})$ & $\mathrm{T}(\mathrm{N} \cdot \mathrm{m})$ \\
\hline 3 & 0,108 \\
\hline
\end{tabular}

\subsubsection{Analisa pergerakan motor stepper}

1. Untuk menghitung putaran motor jika diketahui putaran rol $58 \mathrm{rpm}$ dan perbandingan sproket 28:12 dapat menggunakan persamaan 6 berikut :

$$
\omega_{1}=\omega_{2} \frac{28}{12}
$$

Dimana $\omega_{1}$ adalah kecepatan putar motor dan $\omega_{2}$ kecepatan putar rol. 
2. Hubungan electromotive force dengan kecepatan putaran dapat dihasilkan menggunakan persamaan 7 berikut [3].

$$
E_{b}=K_{E} \cdot \omega
$$

Dimana $E_{b}$ adalah electromotive force (volt), $\omega$ adalah kecepatan putaran (rpm), dan $K_{E}$ adalah Konstanta tegangan.

3. Hubungan antara tegangan dan arus pada motor stepper dapat dihasilkan dengan persamaan 8 berikut [3].

$$
V(t)=L \frac{d I(t)}{d t}+R \cdot I(t) E_{b}
$$

Dimana V(t) adalah tegangan (volt), L adalah induktansi koil (H), R adalah hambatan (ohm), I adalah arus (A), dan Eb adalah electromotive force (volt).

4. Torsi yang dihasilkan pada motor stepper medan magnet konstan proporsional dengan arus yang dihasilkan, menggunakan persamaan 9 berikut [3].

$$
\mathrm{T}=\mathrm{K}_{\mathrm{T}} \cdot \mathrm{I}
$$

Dimana T adalah torsi motor (kg-m), $\mathrm{K}_{\mathrm{T}}$ adalah konstanta torsi (Nm/A) dan I adalah Arus (A).

5. Hubungan kecepatan putaran dalam rps dan kecepatan linear plastik :

$$
\mathrm{V}=\frac{2 \cdot \pi \cdot \mathrm{n} \cdot \mathrm{r}}{60}
$$

Dimana $\mathrm{V}$ adalah kecepatan linear $(\mathrm{m} / \mathrm{s}), \mathrm{n}$ adalah kecepatan putaran rol (rpm), $\mathrm{r}$ adalah jari-jari rol plastik (m).

6. Input kecepatan putaran ditentukan oleh frekuensi pulsa untuk menggerakkan motor stepper setiap detik dapat ditentukan menggunakan persamaan 11 berikut [3].

$$
f=\frac{\mathrm{N} \cdot \mathrm{n}}{60}
$$

Dimana $\mathrm{f}$ adalah frekuensi (Hz), $\mathrm{N}$ adalah jumlah step, $\mathrm{n}$ adalah kecepatan putar motor (rpm). Hasil perhitungan pergerakan motor stepper di tunjukkan pada tabel 3 .

Tabel. 3 Perhitungan pergerakan motor stepper

\begin{tabular}{cccccc}
\hline$\omega 1(\mathrm{rpm})$ & $\mathrm{Eb}($ volt $)$ & $\mathrm{V}(\mathrm{t})($ volt $)$ & $\mathrm{T}(\mathrm{kg}-\mathrm{m})$ & $\mathrm{V}(\mathrm{m} / \mathrm{s})$ & $f(\mathrm{~Hz})$ \\
\hline 135 & 9,531 & 15,923 & 1,54 & 0,3 & 450 \\
\hline
\end{tabular}

\subsection{Desain Sistem Kontrol}

Desain sistem kontrol di bawah ini menunjukakan cara kerja sistem kontrol putaran motor stepper berawal dari power supply yang mengubah arus AC menjadi DC yang dihubungkan ke mikrokontroller, 
kemudian mikrokontroller yang sudah terprogram akan memberikan sinyal ke driver motor yang kemudian driver tersebut akan memberikan sinyal ke motor stepper 1 dan 2 dimana motor stepper 1 akan aktif sehingga akan menggerakkan roll untuk menarik plastik dari tempat plastik dan motor stepper 2 juga aktif yang akan menggerakkan roll panas yang sudah diberi heater untuk proses pengepresan plastik. Desain sistem kontrol mesin pengemas jahe menggunakan sistem kontol open loop yang bisa dilihat pada gambar 3 berikut :

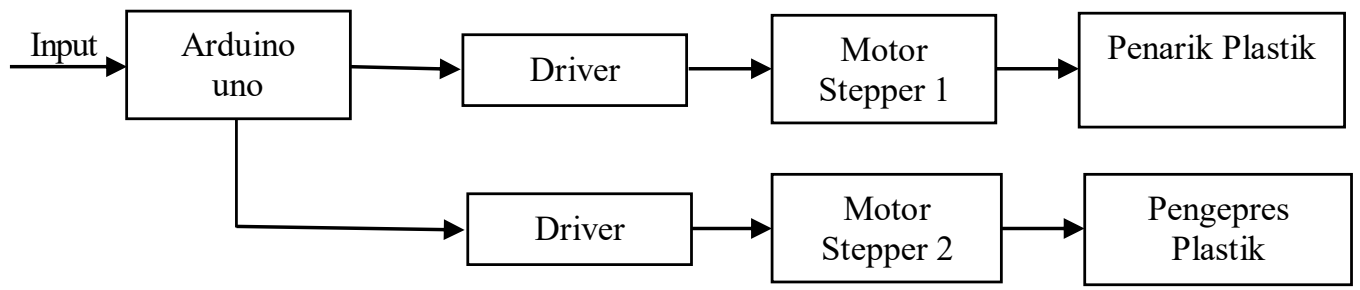

Gambar 3 Desain sistem kontrol mesin pengemas

Desain sistem kontrol penarikan dan pengepresan plastik diawali dengan Input sinyal mikrokontroler Arduino berupa tegangan 5v. Mikrokontroler memberi sinyal ke motor driver untuk memengaktifkan motor stepper 1 dengan pulse 450 per detik dan kecepatan putar motor $135 \mathrm{rpm}$. Motor stepper 1 akan hidup untuk menarik plastik dengan kecepatan rol $58 \mathrm{rpm}$. Mikrokontroler memberi sinyal ke motor driver untuk memengaktifkan motor stepper 2 dengan pulse 450 per detik dan kecepatan putar motor $135 \mathrm{rpm}$. Motor stepper 2 akan hidup untuk pengepresan plastik dengan kecepatan rol $58 \mathrm{rpm}$.

\subsection{Desain Instalasi Hardware Sistem Kontrol}

Pada gambar 4 menujukkan desain instalasi hardware yang diawali dari listrik yang dikonversi dari AC menjadi listrik DC oleh power supply. Pengoperasian sistem kontrol dimulai dari PC yang memasukan skrip perintah pada software Arduino UNO, selanjutnya Arduino UNO mengkonversi berbagai macam perintah meliputi Power supply mengubah sinyal AC menjadi DC kemudian dihubungkan ke mikrokontroller, mikrokontroller memberi sinyal ke motor driver, motor driver akan menguatkan sinyal dan akan memutar motor stepper 1 untuk penarikan plastik dengan kecepatan $135 \mathrm{rpm}$, Motor driver berada didalam box, arduino memberi sinyal ke motor driver 2, motor driver 2 akan menguatkan sinyal dan akan memutar motor stepper 2 untuk proses pengepresan plastik dengan kecepatan $135 \mathrm{rpm}$, motor driver 2 ini juga berada di dalam box sebagai perintah untuk mengaktifkan motor stepper, power supply digunakan untuk mengubah tengan AC menjadi DC, laptop digunakan untuk menginputkan data ke mikrokontroler, mikrokontroler digunakan untuk mengkontrol semua komponen, motor stepper 1 digunakan untuk menarik plastik, motor stepper 2 digunakan untuk proses pengepresan plastik. 


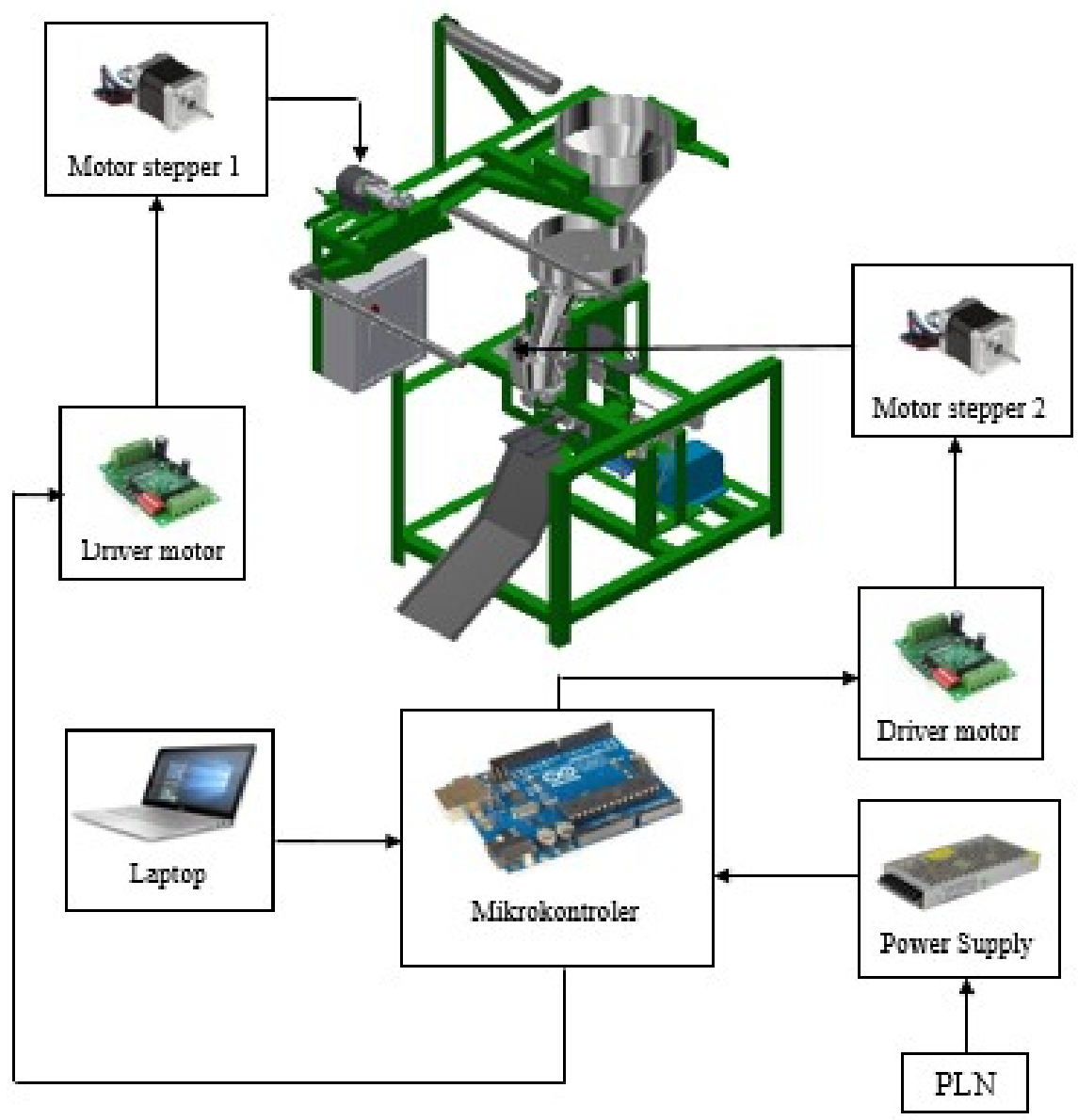

Gambar 4 Desain Instalasi Hardware

\subsection{Alat untuk pembuatan hardware dengan arduino UNO}

Alat yang digunakan pada sistem kontrol mesin pengemas jahe meliputi komputer atau laptop, arduino UNO, motor driver, kabel jamper, papan breadboard, dan power supply

\subsection{Hasil pembuatan hardware}

Hasil pembuatan hardware dapat dilihtat pada gambar 5 yang menjelaskan bahwa hasil pembuatan hardware yang meliputi mikrokontroller arduino UNO, driver motor, dan power supply berada di dalam box. Motor stepper 1 dan motor stepper 2 menempel pada rangka. 


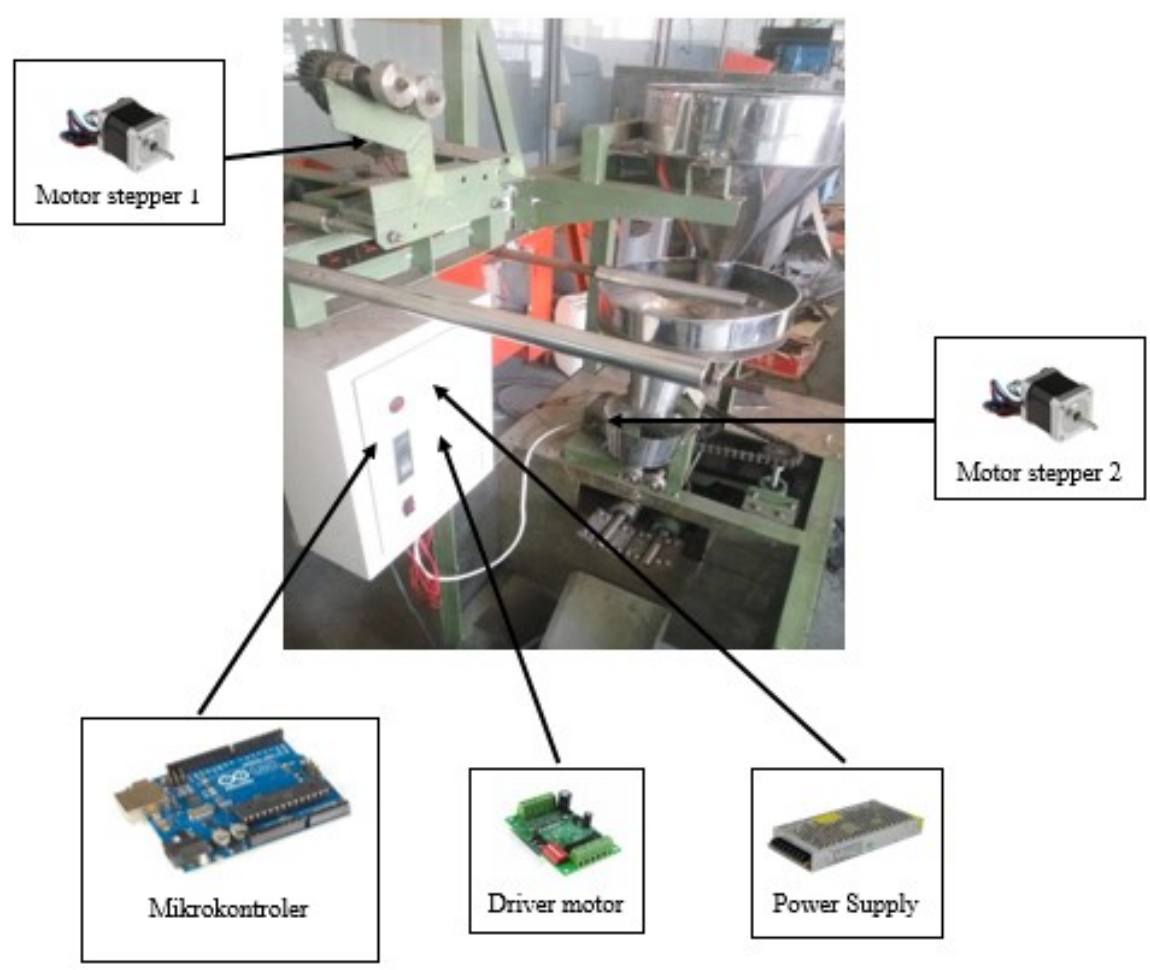

Gambar 5 Hasil pembuatan Hardware

\subsection{Hasil pembuatan hardware didalam box}

Hasil pembuatan rangkaian di dalam box kontrol ditunjukkan pada gambar 6. Terdiri dari komponen power supply, mikrokontroller, driver 1 dan driver 2 .

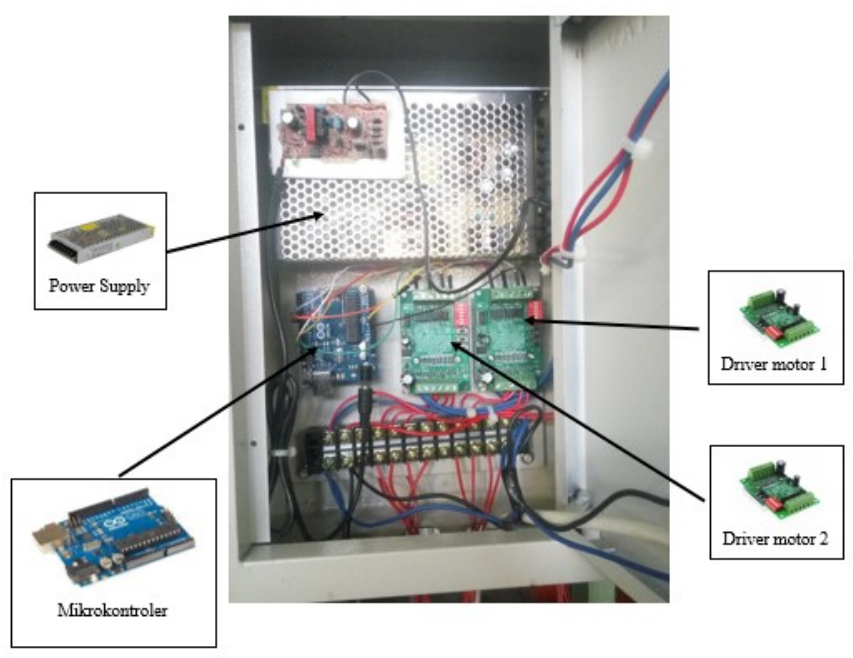

Gambar 6. Box Sistem Kontrol 


\subsection{Pengujian Sistem Kontrol}

\section{Pengujian ketepatan motor stepper}

Pengujian sistem kontrol untuk menguji putaran motor stepper untuk penarikan dan pengepresan plastik dengan perbandingan rasio sproket 28:12 dapat dilihat pada tabel 4 berikut :

Tabel. 4 Hasil pengujian

\begin{tabular}{ccccc}
\hline \multirow{2}{*}{ NO } & \multicolumn{2}{c}{ penarikan plastik } & \multicolumn{2}{c}{ Pengepresan Plastik } \\
\cline { 2 - 5 } & Putaran Motor & Putaran Rol & Putaran Motor & Putaran Rol \\
\hline 1 & 135 & 58 & 135 & 58 \\
2 & 135 & 58 & 135 & 58 \\
3 & 135 & 58 & 135 & 58 \\
\hline
\end{tabular}

Dari hasil pengujian, motor stepper 1 dan 2 dapat berputar dengan kecepatan $135 \mathrm{rpm}$ dan dengan kecepatan rol 58 rpm untuk penarikan dan pengepresan plastik.

Pada hasil pengujian motor stepper 1 yang berfungsi untuk penarikan plastik dapat bekerja dengan baik untuk menarik plastik dari rol penempatan plastik, motor stepper 2 yang berfungsi sebagai pengepresan sisi plastik juga berfungsi dengan baik mengepres sisi plastik dan putaran motor stepper 1 dan 2 ketepatannya sama.

\section{KESIMPULAN}

Penelitian ini telah menghasilkan desain dan rangkaian hardware hasil pembuatan sistem kontrol putaran motor stepper pada mekanisme penarikan dan pengepresan plastik. Hasil pengujian menunjukkan bahwa ketepatan putaran motor stepper dengan kecepatan motor stepper 1 sebagai penarik plastik sebesar $135 \mathrm{rpm}$ dan kecepatan rol $58 \mathrm{rpm}$, motor stepper 2 sebagai pengepres plastik berputar dengan kecepatan 135 rpm dan kecepatan rol $58 \mathrm{rpm}$.

\section{DAFTAR PUSTAKA}

[1] D. L. Zariatin, E. H. O. Tambunan, and A. Suwandi, "Rancang Bangun Simulator Sistem Pengepakan Produk Berbasis Progammable Logic Control,” SINTEK, vol. 10, no. 2, pp. 28-35, 2016.

[2] S. Hutubessy, 2006, "Kendali Motor Stepper Dengan Komunikasi Serial Berbasis Mikrokontroller AT89S51," Skripsi, Tek. Elektro, Univ. Sanata Dharma.

[3] A. Budiman, 2017, "Perancangan Sistem Kontrol Posisi dan Pengepresan Plastik Untuk Proses Pengemasan Deterjen," Skripsi, Tek. mesin, Universitas Muria Kudus.

[4] S. Y. Dimpudus, E. V. C. Poekoel, and P. D. K. Manembu, 2015, "Sistem Pengepakan Botol Minuman Kemasan Berbasis Programmable Logic Controller," E-Journal Tek. Elektro dan Komput., vol. 4, no. 7, pp. 65-72.

[5] P. Kushartanto, M. Kabib, and R. Winarso, "Sistem Kontrol Gerak dan Perhitungan Produk pada Mesin Pres dan Pemotong Kantong Plastik," Jurnal CRANKSHAFT, vol. 2, no. 1, pp. 57-66, 2019.

[6] F. Syarifudin and B. Anto, 2017, "Rancang Bangun Saklar Pemindah Otomatis Berpenggerak Motor Stepper Variable Reluctance Dengan Pengendali Mikrokontroler ATMega8535," Jom FTEKNIK, vol. 4, no. 2, pp. 1-10.

[7] Miftah, 2013 "Implementasi Metode Kuzzy Logic Sugeno Pada Pengaturan Suhu Ruang Penyimpanan Berbasis Mikrokontroler,” Perpust. Univ. Pendidik. Indones., pp. 1-10.

[8] B. Ibrahim and M. E. Oktavian, "Perancangan konstruksi dan biaya mesin pengemas roti untuk industri kecil," vol. 2, no. 1, pp. 1-7. 